\title{
The structure and content of regionally-focused concepts as the core of personal regional identity
}

Lyudmila A. Maksimova, Ravil' A. Valiev, Natalya B. Ruzhentseva, Tatiana V. Valieva, and Nadezhda Kulikova

Ural State Pedagogical University and Ural State Medical University, Yekaterinburg, Russia

Factor analysis let us to outline the 7-factor structure of the regional identity conceptual sphere, which includes the identification, social-spatial, subjectiveattributive, existential, cultural-informative, personal, and axiological-symbolic factors.

The factor structure of the Sverdlovsk region resident's regional identity conceptual sphere

\begin{tabular}{|c|c|}
\hline \multicolumn{2}{|r|}{ Variables } \\
\hline Factor 1 & $\begin{array}{l}\text {-The Romanov family - Russian tsars and emperors dynasty } \\
\text {-Demidov Akinfiy Nikitich - the founder of the Urals mining industry } \\
-96,66 \text { - the Sverdlovsk region vehicle registration code } \\
\text {-Plants }\end{array}$ \\
\hline Factor 2 & $\begin{array}{l}\text {-Significant Yekaterinburg streets } \\
\text {-1905 Square - the square in Yekaterinburg city centre, the "main" square of the city } \\
\text {-Shopping centre Tagansky Ryad } \\
\text {-The Iset - the river in the Urals flowing in the Sverdlovsk region } \\
\text {-Theatres }\end{array}$ \\
\hline Factor 3 & $\begin{array}{l}- \text { Relatives } \\
\text {-City } \\
\text {-Dirt } \\
\text {-Mountains }\end{array}$ \\
\hline Factor 4 & $\begin{array}{l}\text {-Education } \\
\text {-Money } \\
\text {-Friends } \\
\text {-Family } \\
\text {-Home } \\
\end{array}$ \\
\hline Factor 5 & $\begin{array}{l}\text {-Libraries } \\
\text {-Tatischev - the founder of Yekaterinburg } \\
\text {-Museums } \\
\text {-Theatres }\end{array}$ \\
\hline Factor 6 & $\begin{array}{l}\text {-Life } \\
\text {-Love } \\
\text {-People } \\
\text {-Family } \\
\text {-Home } \\
\text {-Mountains }\end{array}$ \\
\hline Factor 7 & $\begin{array}{l}\text {-Ganina Yama - the place of the royal remains burial in } 1918 \\
\text {-The Nevyansk Tower- the symbol of Nevyansk } \\
\text {-Olenyi Ruchyi - the nature park in the Sverdlovsk region } \\
\text {-Church on Blood -the operating orthodox church built in the place of the Romanov } \\
\text { family's execution } \\
\text {-Plants }\end{array}$ \\
\hline
\end{tabular}

The next step of our research was devoted to identification of the respondents' individual factor scores and elicitation of the differences in the regional identity components representation among higher education and college students. The analysis revealed significant differences between higher education and college students in the identification and cultural-informative components of regional identity.

\begin{tabular}{|c|c|c|c|c|c|}
\hline $\begin{array}{c}\text { Factor } \\
\text { no. }\end{array}$ & Factor & $\begin{array}{c}\text { Average value in } \\
\text { higher education } \\
\text { students sample }\end{array}$ & $\begin{array}{c}\text { Average value } \\
\text { in college } \\
\text { students } \\
\text { sample }\end{array}$ & $\begin{array}{c}\text { Empirical } \\
\text { value, } \mathbf{t}\end{array}$ & $\begin{array}{c}\text { Significance } \\
\text { value, } \mathbf{p}\end{array}$ \\
\hline 1 & Identification & 0,32 & $-0,28$ & 3,29 & 0,00 \\
\hline 5 & $\begin{array}{c}\text { Cultural- } \\
\text { informative }\end{array}$ & $-0,26$ & 0,22 & $-2,58$ & 0,01 \\
\hline
\end{tabular}

The conducted research leads to the following conclusions. Such concepts as "Mountains", "Plants", "Rivers", "Settlements of the Sverdlovsk region", "the Iset river", "Church on Blood" are represented in the respondents' (young residents of the Sverdlovsk region) consciousness most often. The factor structure of the regional identity conceptual sphere in adolescence contains such components as the identification, social-spatial, subjective-attributive, existential, cultural-informative, personal and axiological-symbolic ones. The differences in representation of the identification and culturalinformative components were revealed between higher education and college students. 